\title{
Updates of CORESTA Recommended Methods after Further Collaborative Studies Carried Out under Both ISO and Health Canada Intense Smoking Regimes*
}

\author{
by \\ Stephen W. Purkis ${ }^{1}$, Michael Intorp ${ }^{2}$, and Alexander Hauleithner ${ }^{3}$ \\ ${ }^{1}$ Imperial Tobacco Limited, Winterstoke Road, Bristol BS3 2LL, UK \\ ${ }^{2}$ Imperial Tobacco Group, Albert-Einstein-Ring 7, 22761 Hamburg, Germany \\ ${ }^{3}$ Japan Tobacco International, Hasnerstrasse 127, 1160 Vienna, Austria
}

\section{SUMMARY}

During 2012, three CORESTA Recommended Methods (CRMs) (1-3) were updated to include smoke yield and variability data under both ISO (4) and the Canadian Intense (CI) (5) smoking regimes. At that time, repeatability and reproducibility data under the $\mathrm{CI}$ regime on smoke analytes other than "tar", nicotine and carbon monoxide (6) and tobacco-specific nitrosamines (TSNAs) (7) were not available in the public literature. The subsequent work involved the determination of the mainstream smoke yields of benzo $[a]$ pyrene, selected volatiles (benzene, toluene, 1,3-butadiene, isoprene, acrylonitrile), and selected carbonyls (acetaldehyde, formaldehyde, propionaldehyde, butyraldehyde, crotonaldehyde, acrolein, acetone and 2-butanone) in ten cigarette products followed by statistical analyses according to the ISO protocol (8). This paper provides some additional perspective on the data variability under the ISO and CI smoking regimes not given in the CRMs. [Beitr. Tabakforsch. Int. 25 (2013) 700-707]

\section{ZUSAMMENFASSUNG}

Im Jahr 2012 wurden drei von der CORESTA empfohlene Methoden (CORESTA Recommended Methods, CRM) (1-3) aktualisiert, um Daten zu Rauchausbeuten und Variabilität nach den Verfahren zur Messung des Tabakkonsums gemäß ISO (4) und Canadian Intense (CI) (5) aufzunehmen. Zu dieser Zeit standen Daten zur Wiederholgenauigkeit und Reproduzierbarkeit nach dem CI-Verfahren zu Rauchanalyten, abgesehen von Teer, Nikotin und Kohlenmonoxid (6) sowie tabakspezifischen Nitrosaminen (TSNA)
(7), in der öffentlich zugänglichen Literatur nicht zur Verfügung. Die folgende Arbeit umfasste die Bestimmung der Ausbeuten im Hauptstromrauch an 700707Benzo[a]pyren, ausgewählten flüchtigen Bestandteilen (Benzol, Toluol, 1,3-Butadien, Isopren, Acrylnitril) und ausgewählten Carbonylverbindungen (Acetaldehyd, Formaldehyd, Propionaldehyd, Butyraldehyd, Crotonaldehyd, Acrolein, Aceton und 2-Butanon) in zehn Zigarettenprodukten gefolgt von statistischen Analysen nach dem ISO-Protokoll (8). In dieser Arbeit wird eine neue Sichtweise auf die Datenvariabilität bei den ISO- und CI-Messverfahren aufgezeigt, die in den CRM nicht enthalten war. [Beitr. Tabakforsch. Int. 25 (2013) 700-707]

\section{RESUME}

Au cours de 2012, trois méthodes recommandées par la CORESTA (CRM) (1-3) ont été actualisées pour inclure les données de variabilité et de rendement du flux de fumée principal obtenues en utilisant les régimes de fumage ISO (4) et Canadian Intense (CI) (5). À ce moment-là, les données de répétabilité et de reproductibilité sous le régime $\mathrm{CI}$ concernant les analytes de fumée autres que le goudron, la nicotine et le monoxyde de carbone (6) ainsi que les nitrosamines spécifiques du tabac (TSNA) (7) n'étaient pas disponibles dans la documentation publiée. Les travaux qui ont suivi impliquaient la détermination des teneurs du flux de fumée principal en benzo[ $a]$ pyrène, en composants volatiles sélectionnés (benzène, toluène, buta-1,3-diène, isoprène, acrylonitrile) et en carbonyles sélectionnés (aldéhyde acétique, aldéhyde formique, aldéhyde propionique, aldéhyde butyrique, aldéhyde crotonique, acroléine, acétone et 
2-butanone) dans dix produits de cigarettes, suivie par des analyses statistiques conformément au protocole ISO (8). Le présent rapport fournit des perspectives supplémentaires sur la variabilité des données avec les régimes de fumage ISO et CI, qui ne sont pas fournies par les CRM. [Beitr. Tabakforsch. Int. 25 (2013) 700-707]

Tobacco-specific nitrosamine (TSNA) yields in mainstream smoke and associated variability data had previously and similarly been determined for the same cigarette products under both smoking regimes as described in another CRM (7) and discussed in a published paper (9). Additional papers have been published previously in this journal on the development and learning leading to the approved CRMs carried out under the ISO smoking regime for the currently discussed analytes (10-12).

This body of work has demonstrated that method standardization is not always straightforward, but is the result of a process of conducting joint experiments to investigate the effect of important parameters or steps in the method that have the most impact on yield variability. Open discussions with a wide range of experts from various laboratories are beneficial in identifying the optimal parameters of the methodology. A full collaborative study according to the approved recommended method is put in place only after this process has occurred and a consensus has been reached among participants that the method is understandable, workable and does not contain obvious flaws that should be rectified. Afterwards, further guidance notes are then put into the CRM to provide clarity for various steps. However, the CRMs are not intended to instruct the laboratory on how to carry out their internal validation procedures; guidance notes are mainly intended to highlight and provide advice on parts of the methodology that might need special attention.
The updates on these three CRMs (1-3) followed the preceding process. As a first step, a joint experiment by 14 laboratories was conducted during 2011 with two reference cigarettes $(3 \mathrm{R} 4 \mathrm{~F}$ and $1 \mathrm{R} 5 \mathrm{~F})$. It was determined that the trapping systems for benzo $[a]$ pyrene, selected volatiles and selected carbonyls were adequate for use under the CI smoking regime. Then, CRMs were updated through a final collaborative study involving 12-19 laboratories. In the final studies, laboratories were asked to use the modified CRMs and to apply the number of cigarettes smoked per run as recommended for the CI smoking regime and now included in the finished CRMs.

Information on the listed analytes, the number of participants, the smoking regimes, and the number of outliers removed is provided in Table 1. Each laboratory analysed five replicates under both the ISO and CI regimes. A similar and relatively low number of Grubbs and Cochran outliers was found for data derived under both smoking regimes.

Table 2 shows the respective smoking machine type used by each laboratory for each analyte group. It can be observed that laboratories do not necessarily use the same machine type for collection of each analyte group and each has its own internal criteria for making the choice of machine.

Table 3 shows that for vapour phase compounds collected under the CI smoking regime, mean yields tended to be slightly higher for many, but not all analytes using the linear rather than the rotary smoking machine. However, linear-machine yields were consistently higher across all products for isoprene, acetaldehyde and crotonaldehyde (See Table 3). Higher water yields have also been previously observed on linear machines under CI smoking (6). It can be seen that consistent trends were not found across all the analytes for every product. No statistical significance was assigned to these observations and results

Table 1. Summary of analytes and the number of outliers.

\begin{tabular}{|c|c|c|c|c|c|}
\hline \multirow{3}{*}{ Analyte class } & \multirow{2}{*}{$\begin{array}{c}\text { Smoking regime } \\
\text { Outlier type }\end{array}$} & \multicolumn{2}{|c|}{ ISO smoking regime } & \multicolumn{2}{|c|}{$\mathrm{Cl}$ smoking regime } \\
\hline & & Cochran & Grubbs & Cochran & Grubbs \\
\hline & Outlier number $(\mathrm{N})$ & $\mathrm{N}$ & $\mathrm{N}$ & $\mathrm{N}$ & $\mathrm{N}$ \\
\hline \multirow{8}{*}{$\begin{array}{l}\text { Selected carbonyls } \\
\text { Data obtained from } 19 \\
\text { laboratories }\end{array}$} & 2-butanone & 3 & 1 & 4 & 2 \\
\hline & acetaldehyde & 6 & 0 & 8 & 2 \\
\hline & acetone & 4 & 1 & 6 & 1 \\
\hline & acrolein & 5 & 1 & 8 & 3 \\
\hline & butyraldehyde & 4 & 0 & 6 & 0 \\
\hline & crotonaldehyde & 9 & 1 & 7 & 1 \\
\hline & formaldehyde & 7 & 1 & 2 & 1 \\
\hline & propionaldehyde & 2 & 0 & 5 & 0 \\
\hline \multirow{5}{*}{$\begin{array}{l}\text { Selected volatiles } \\
\text { Data obtained from } 16 \\
\text { laboratories }\end{array}$} & 1,3-butadiene & 1 & 0 & 7 & 0 \\
\hline & benzene & 4 & 0 & 3 & 0 \\
\hline & toluene & 10 & 0 & 10 & 0 \\
\hline & acrylonitrile & 2 & 0 & 3 & 3 \\
\hline & isoprene & 3 & 0 & 1 & 1 \\
\hline $\begin{array}{l}\text { Polyaromatic hydrocarbons } \\
\text { Data obtained from } 12 \\
\text { laboratories }\end{array}$ & benzo[a]pyrene & 8 & 0 & 4 & 0 \\
\hline
\end{tabular}


Table 2. Machine types used by participating laboratories.

\begin{tabular}{l|l|l}
\hline Analyte group & Coded lab numbers using rotary machine & Coded lab numbers using linear machine \\
\hline Selected carbonyls & $5,6,8,9,12,13,14,16$ & $1,2,3,4,7,10,11,15,17,18,19$ \\
Selected volatiles & $2,3,5,8,12,13,16,18,19$ & $1,4,7,10,14,15,17$ \\
Benzo[a]pyrene & $3,4,5,12,13,18,19$ & $7,8,10,11,15$ \\
\hline
\end{tabular}

suggest that the different machine setups do not affect yields of these analytes as much as water.

The overall $r$ and $R$ values can be found in the CRMs (1-3) and were determined after outlier removal irrespective of the smoking machine type used. Mean yields have been extracted and plotted against $\mathrm{R}$ values in Figures 1 to 8 for only a selection of these analytes, to minimize the number of graphs presented and reflecting those analytes with potentially higher regulatory interest.

However, these figures are illustrative of trends for the other analytes. The statistical analysis had computed $r$ and $\mathrm{R}$ values for analyte yields separated by smoking machine type, as this information was provided by the laboratories. However, it is not possible to make consistent conclusions across all analytes or across all products (not shown in this paper).

Similar exercises have been carried out previously on collaborative study data obtained by ISO Working Group 10 (6) and by CORESTA (13) on mean yields, $r$ and $R$ values for nicotine free dry particulate matter (NFDPM), nicotine, carbon monoxide ( $\mathrm{CO})$, and water.

That work showed there are significant differences in water yields obtained from the different machine types under the CI smoking regime and also significantly increased $R$ values for water and NFDPM than under ISO smoking. The relationship between $\mathrm{R}$ and mean yield for nicotine and $\mathrm{CO}$ correlated much better between the two regimes, although there was more scatter around the correlation line with the CI data than the ISO data indicating less robustness concerning the estimation of $\mathrm{R}$.

In the same way as reported for nicotine (6), the tobacco specific nitrosamines had similar or only slightly worse reproducibility under the CI compared to the ISO regime. Data from the current study on selected volatiles, carbonyls and benzo[a]pyrene give some similar findings as summarised below.

1. For data collected under the ISO smoking regime, the correlation between each mean analyte yield and $\mathrm{R}$ values was similar between data from the present collaborative study and previous studies in 2003 (for benzo[ $a]$ pyrene), in 2009 (for selected volatiles) and in 2010 (for selected carbonyls).

2. Some improvements in the reproducibility of some analytes (for example, crotonaldehyde) can be observed as laboratories obtained greater experience in running the methods.

3. For the correlation between mean yields and $\mathrm{R}$ values for vapour phase compounds, there was much more scatter of data than under the ISO regime (Figures 1-7) and a robust estimate of $\mathrm{R}$ values may be difficult to determine. Such $\mathrm{R}$ values may be required in the future to help establish realistic measurement tolerances for regulatory purposes (6).

4. For the particulate phase compound, benzo $[a]$ pyrene, the correlation between mean yields and $\mathrm{R}$ values was similar for data collected under both the ISO and CI regimes, although there was rather more scatter around any imposed correlation line (see Figure 8). Results were therefore similar to those found for other particulate phase compounds, that is, nicotine (6) and TSNAs (7). There were no obvious effects of machine type on smoke yields or their variability.

Table 3. Yield differences between linear and rotary smoking machines.

\begin{tabular}{|c|c|c|c|c|c|c|c|}
\hline \multirow{2}{*}{ Product } & \multicolumn{7}{|c|}{$\begin{array}{l}\% \text { Increase of linear yield on rotary yield }= \\
\text { (linear yield }- \text { rotary yield) } \times 100 / \text { rotary yield }\end{array}$} \\
\hline & 1,3-Butadiene & Isoprene & Benzene & Formaldehyde & Acetaldehyde & Acrolein & Crotonaldehyde \\
\hline CM6 & +3.2 & +4.6 & +9.4 & +1.6 & +13.7 & +7.0 & +10.2 \\
\hline 1R5F & -2.0 & +8.9 & +13.4 & -14.0 & +11.5 & -2.9 & +4.5 \\
\hline $3 \mathrm{R} 4 \mathrm{~F}$ & -1.2 & +12.4 & +11.9 & -0.2 & +7.1 & +3.6 & +10.5 \\
\hline 1 & -5.6 & +5.3 & +5.4 & -10.4 & +3.2 & -2.7 & +4.3 \\
\hline 2 & -12.7 & +6.3 & +5.1 & -2.9 & +0.9 & +2.2 & +8.5 \\
\hline 3 & -9.3 & +8.7 & +5.6 & -2.4 & +3.8 & +0.8 & +8.5 \\
\hline 4 & +1.7 & +6.5 & +13.3 & -2.8 & +6.3 & -1.6 & +6.0 \\
\hline 5 & +10.7 & +11.7 & +14.2 & +7.1 & +11.7 & +0.8 & +1.1 \\
\hline 6 & +3.3 & +12.6 & +9.8 & +3.7 & +2.6 & +1.5 & +7.2 \\
\hline 7 & -1.5 & +1.2 & -1.4 & -8.7 & +6.1 & +8.9 & +13.4 \\
\hline Average & -1.3 & +7.8 & +8.7 & -2.9 & +6.7 & +1.8 & +7.4 \\
\hline
\end{tabular}




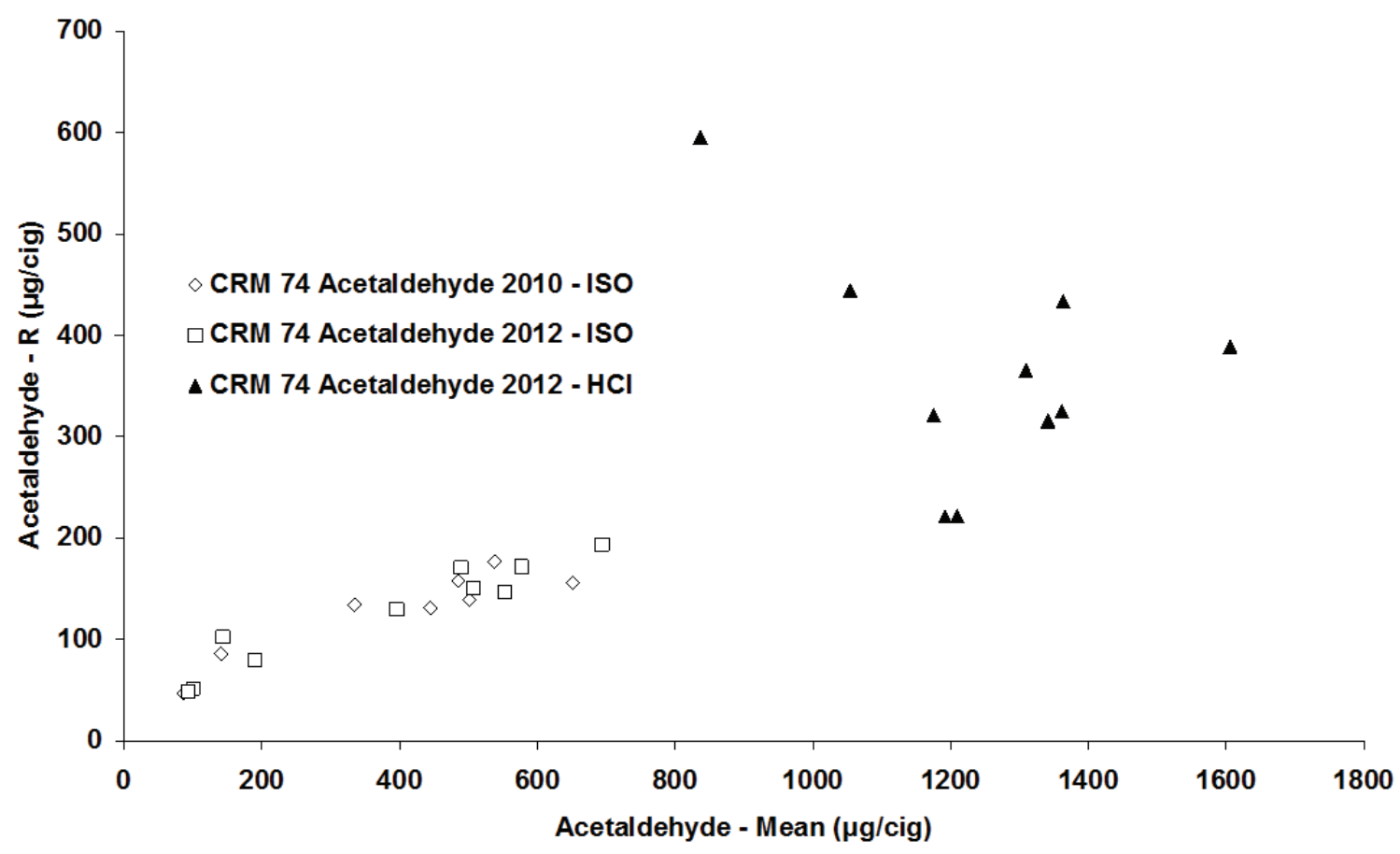

Figure 1. Relationship between mean yield and reproducibility for acetaldehyde yields collected under ISO and $\mathrm{Cl}$ smoking regimes.

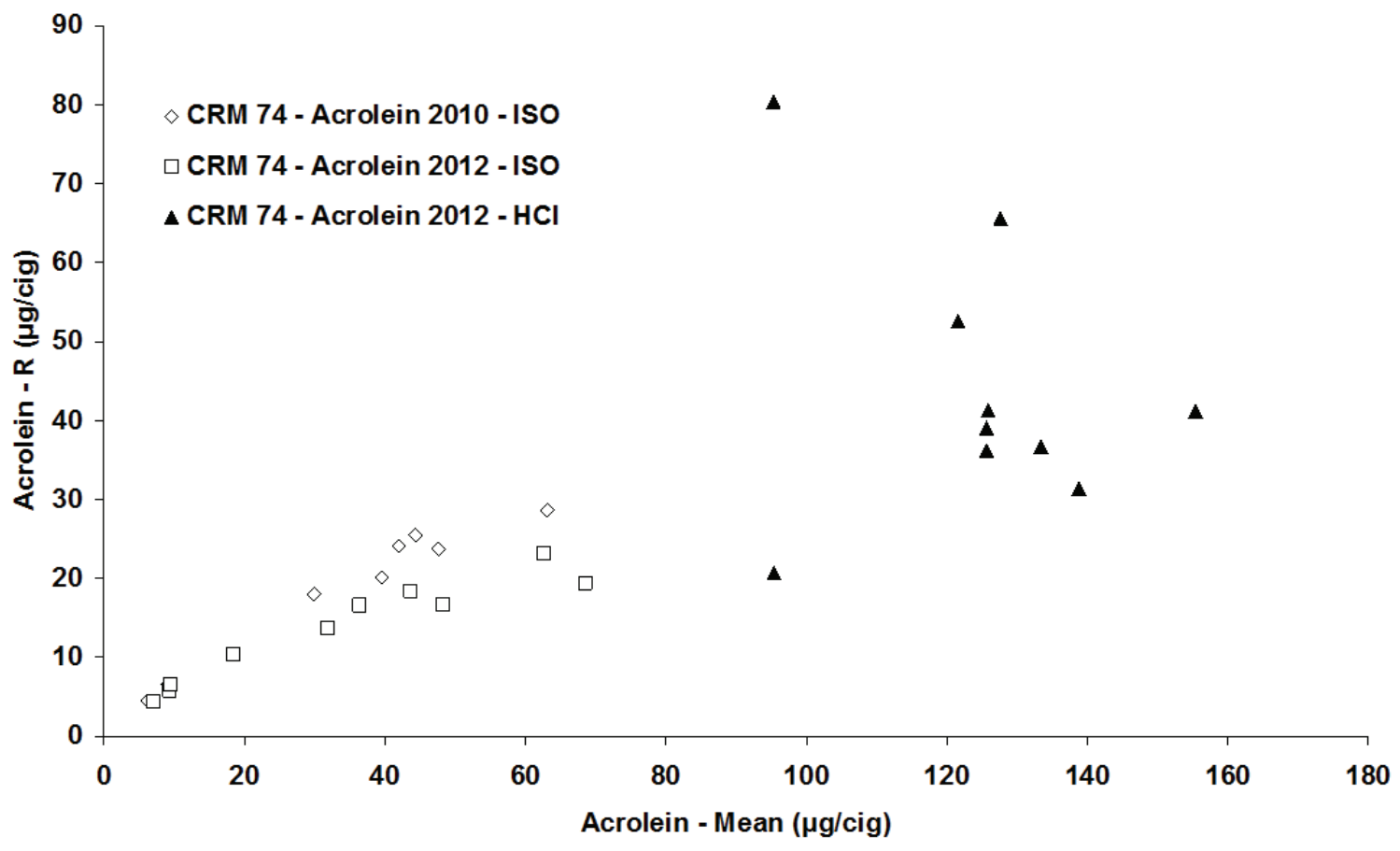

Figure 2. Relationship between mean yield and reproducibility for acrolein yields collected under ISO and $\mathrm{Cl}$ smoking regimes. 


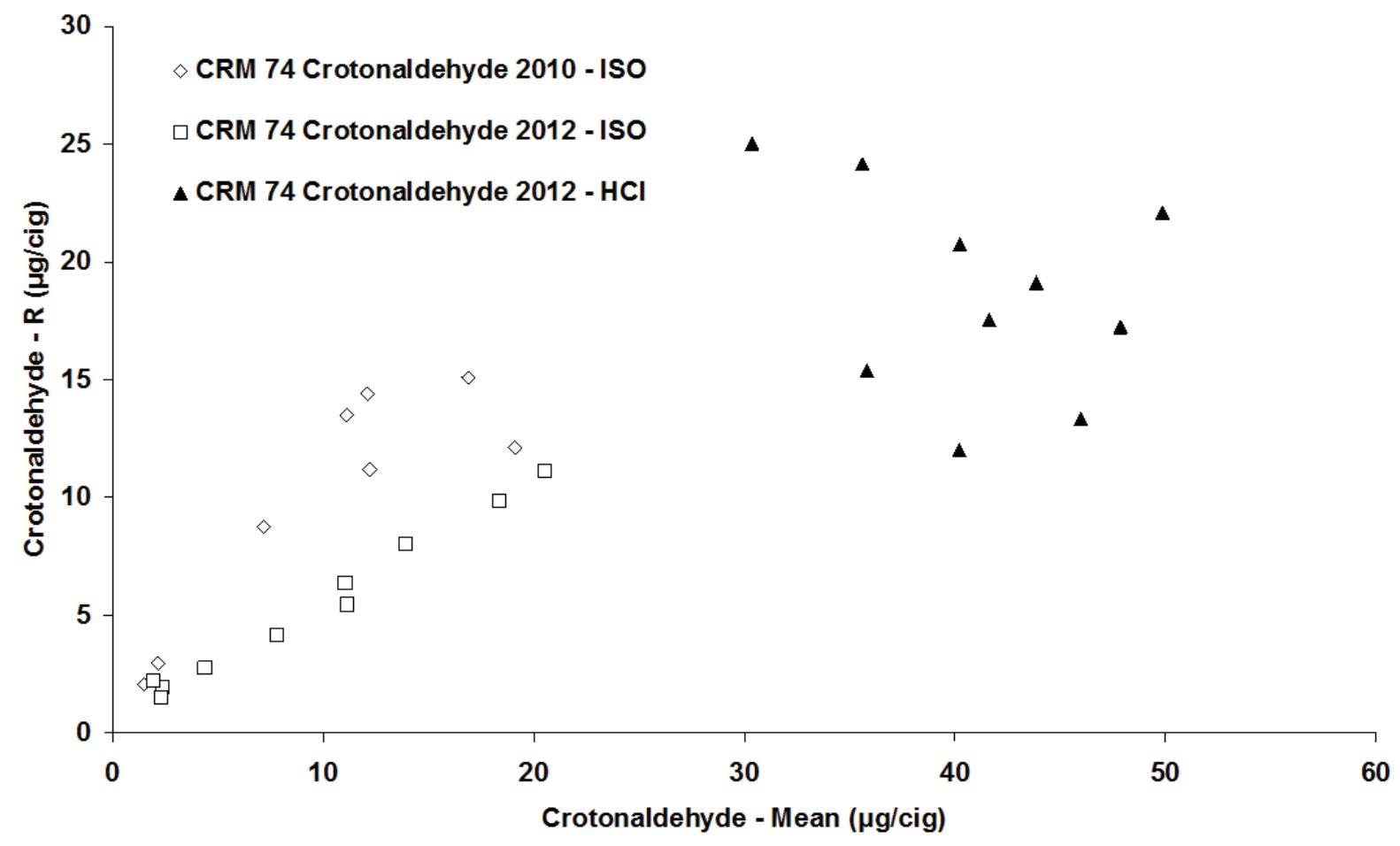

Figure 3. Relationship between mean yield and reproducibility for crotonaldehyde yields collected under ISO and CI smoking regimes.

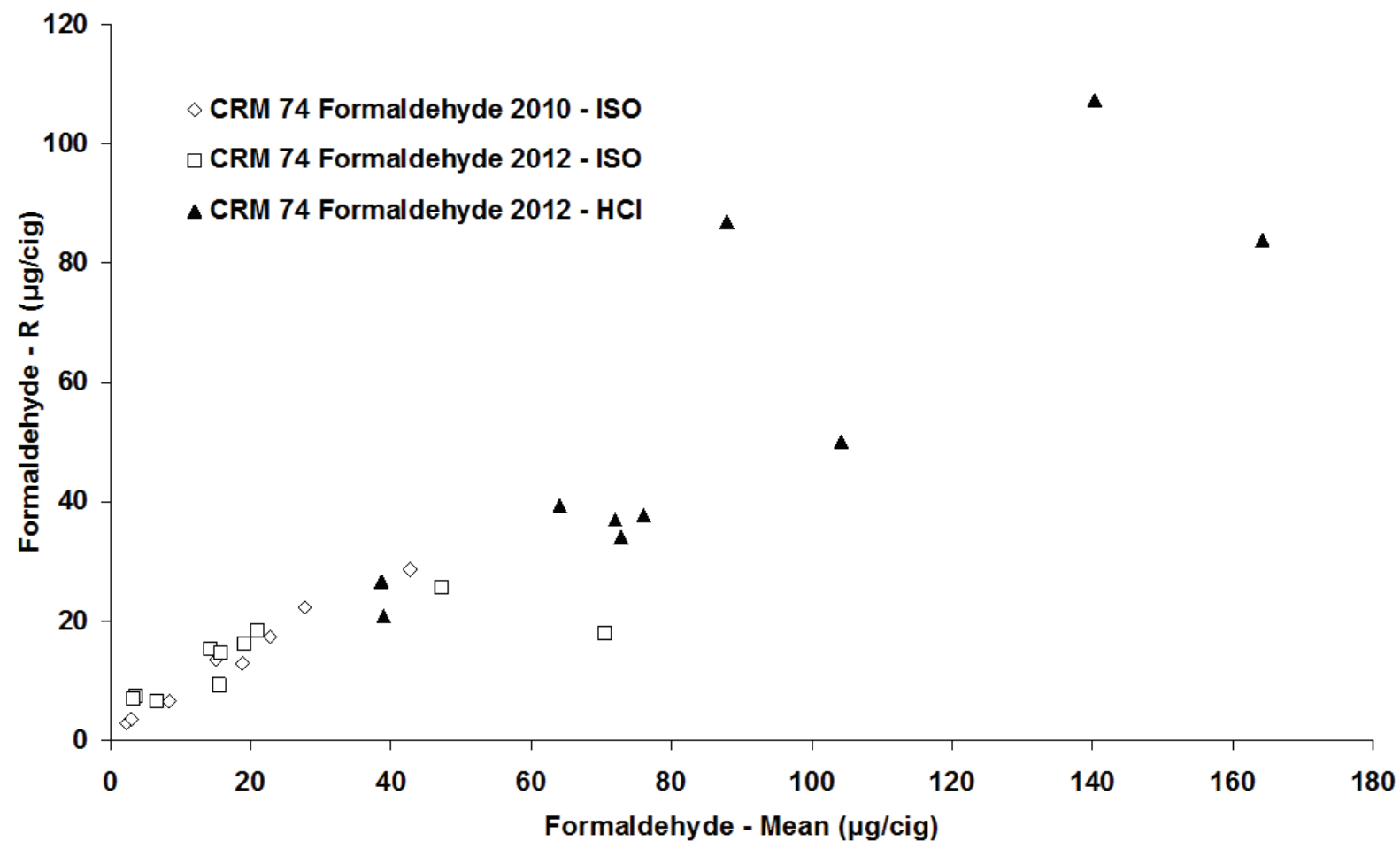

Figure 4. Relationship between mean yield and reproducibility for formaldehyde yields collected under ISO and $\mathrm{Cl}$ smoking regimes. 


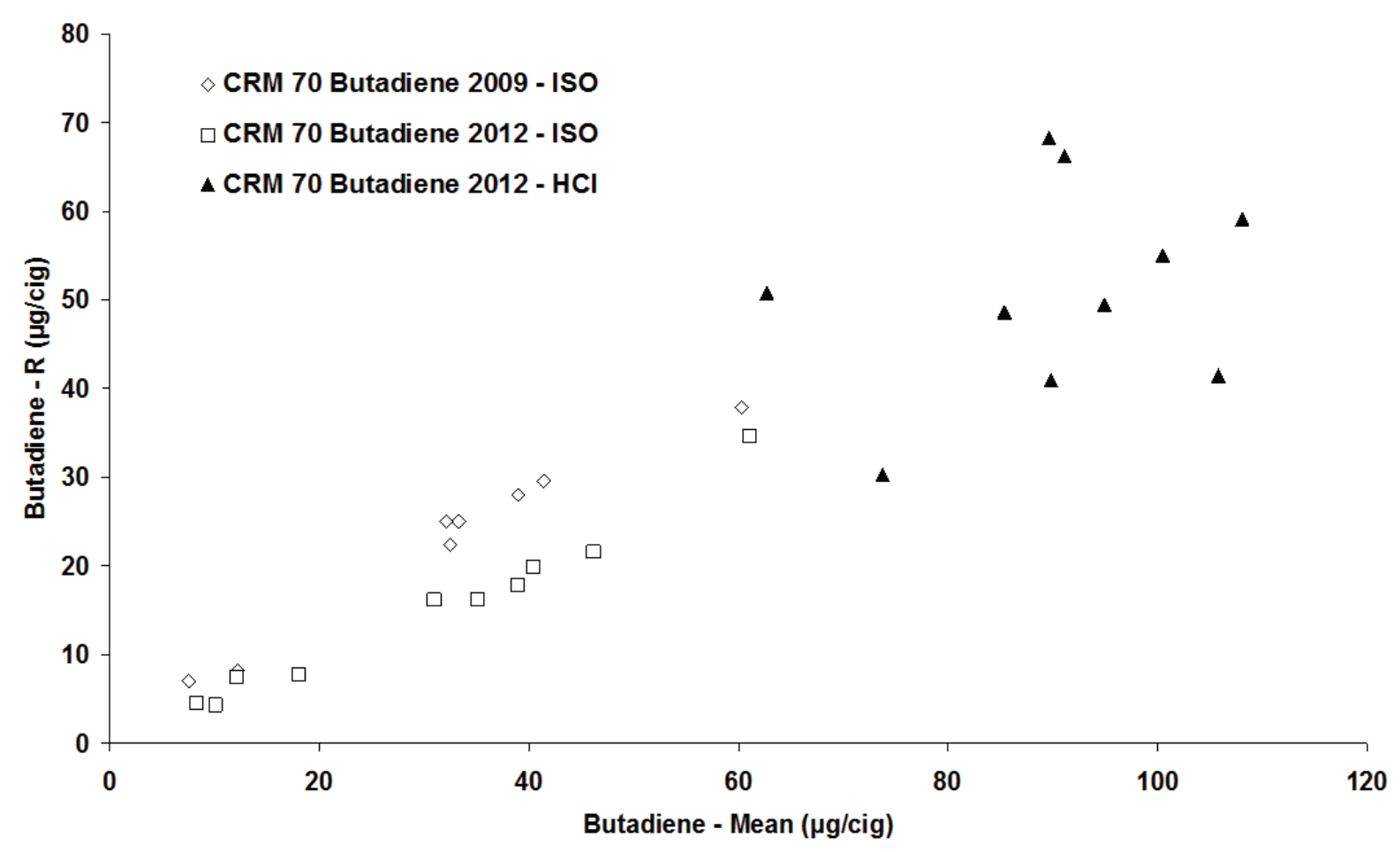

Figure 5. Relationship between mean yield and reproducibility for 1,3-butadiene yields collected under ISO and $\mathrm{Cl}$ smoking regimes.

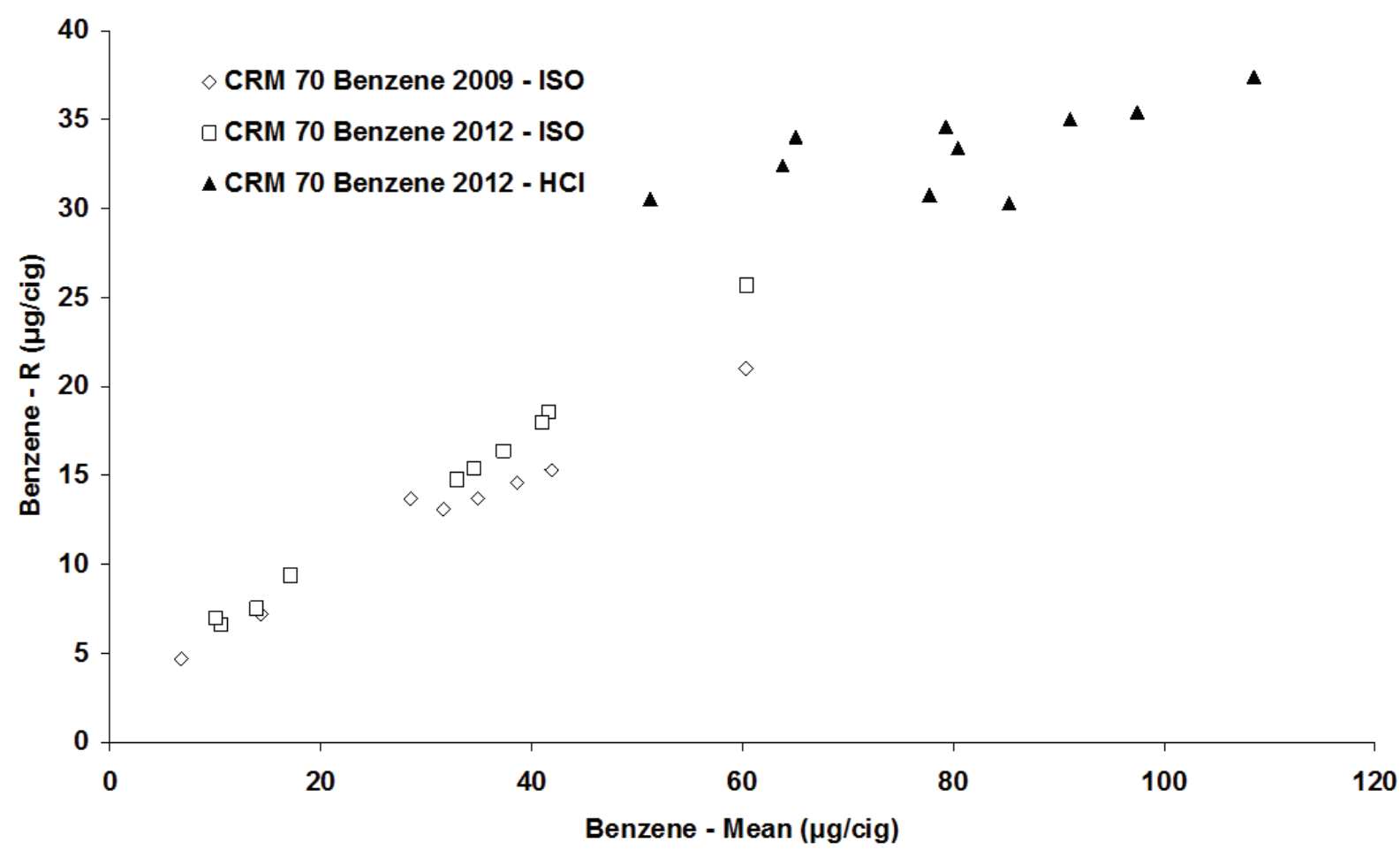

Figure 6. Relationship between mean yield and reproducibility for benzene yields collected under ISO and $\mathrm{Cl}$ smoking regimes. 


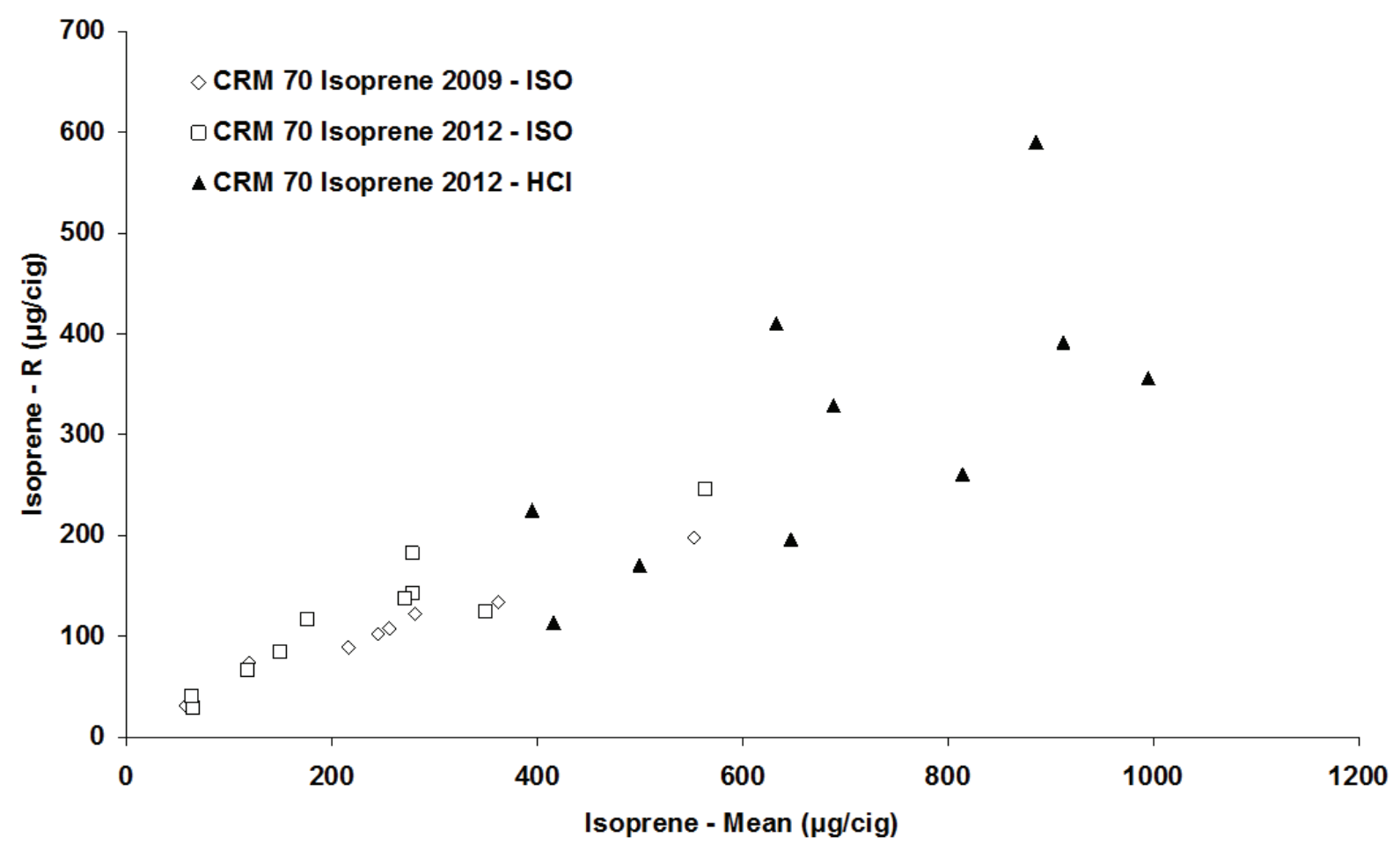

Figure 7. Relationship between mean yield and reproducibility for isoprene yields collected under ISO and $\mathrm{Cl}$ smoking regimes.

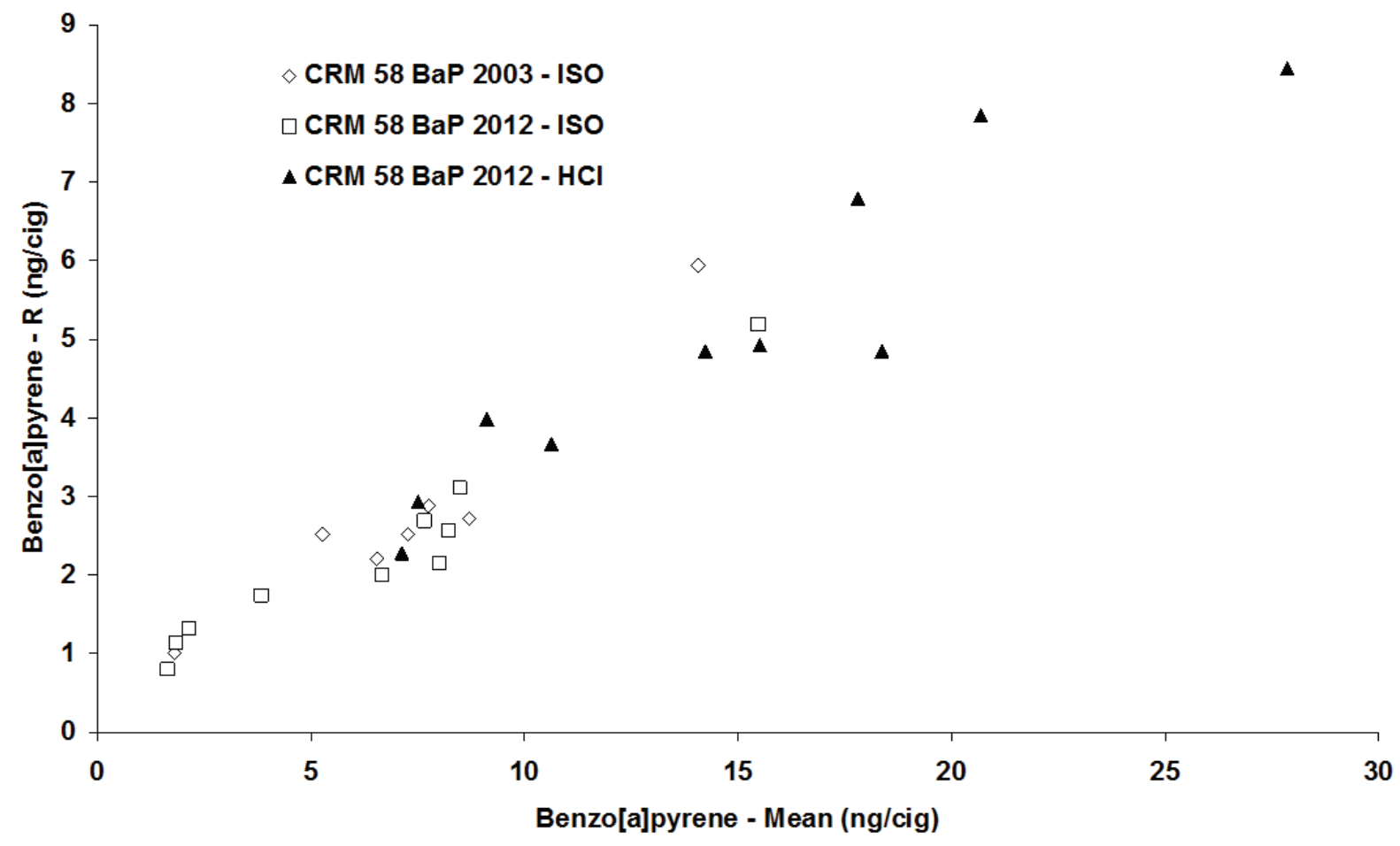

Figure 8. Relationship between mean yield and reproducibility for benzo[a]pyrene yields collected under ISO and CI smoking regimes. 


\section{REFERENCES}

1. CORESTA Recommended Method No. 58: Determination of Benzo $[a]$ pyrene in Mainstream Cigarette Smoke by GC-MS (Updated Version March 2013); Available at http://www.coresta.org/Recommended Methods/CRM 58-update(March13).pdf(Accessed June 2013).

2. CORESTA Recommended Method No. 70: Determination of Selected Volatile Organic Compounds in Mainstream Cigarette Smoke by GC-MS (Updated Version March 2013); Available at http://www. coresta. org/Recommended_Methods/CRM_70-update(March 13).pdf (Accessed June 2013).

3. CORESTA Recommended Method No. 74: Determination of Selected Carbonyls in Mainstream Cigarette Smoke by HPLC) (Updated Version March 2013); Available at http://www.coresta.org /Recommended Methods /CRM_74-update (March13).pdf (Accessed June 2013).

4. International Organisation for Standardisation (ISO): International Standard ISO 3308. Routine Analytical Cigarette-Smoking Machine - Definitions and Standard Conditions; ISO, Geneva, Switzerland, 2000.

5. Health Canada Method: Determination of "Tar", Nicotine and Carbon Monoxide in Mainstream Tobacco Smoke, 1999; Available at http://www.hc-sc.gc.ca/hc-ps /pubs/tobac-tabac/rc/index-eng.php (Accessed October 2012).

6. Mariner, D.C., W.D. Heller, J. Sarabia, S.W. Purkis, M. Meger, H.J. Eberhardt, and M. Czechowicz: The 2010 ISO TC126 Working Group 10 Collaborative Study on Intense Machine Smoking; CORESTA Joint Study Group Meeting, Graz, Austria, 2011, Presentation ST05; Available at http://www.coresta.org/Meetings/Past Abstracts / Graz 2011-SmokeTech.pdf(Accessed June 2013).

7. CORESTA Recommended Method No. 75: Determination of Tobacco-Specific Nitrosamines in Mainstream Cigarette Smoke by LC-MS/MS (June 2012); Available at http://www.coresta.org/Recommended _Methods / CRM_75.pdf (Accessed June 2013).
8. International Organisation for Standardisation (ISO): International Standard ISO 5725-2 Accuracy (Trueness and Precision) of Measurement Methods and Results Part 2: Basic Method for the Determination of Repeatability and Reproducibility of a Standard Measurement Method. ISO, Geneva, Switzerland, 1994.

9. Intorp, M., S.W. Purkis, and W. Wagstaff: Determination of Tobacco Specific Nitrosamines in Cigarette Mainstream Smoke: The CORESTA 2011 Collaborative Study; Beitr. Tabakforsch. Int. 25 (2012) 507-519.

10. Intorp, M. and S.W. Purkis: Determination of Selected Volatiles in Cigarette Mainstream Smoke: The CORESTA 2008 Joint Experiment; Beitr. Tabakforsch. Int. 24 (2010) 174-186.

11. Intorp, M., S.W. Purkis, and W. Wagstaff: Determination of Selected Volatiles in Cigarette Mainstream Smoke: The CORESTA 2009 Collaborative Study and Recommended Method; Beitr. Tabakforsch. Int. 24 (2011) 243-251.

12. Intorp, M., S.W. Purkis, and W. Wagstaff: Determination of Carbonyl Compounds in Cigarette Mainstream Smoke: The CORESTA 2010 Collaborative Study and Recommended Method; Beitr. Tabakforsch. Int. 25 (2012) 361-374.

13. Saint-Jalm, Y., M. F. Borgerding, S.G. Chapman, and W.T. Morgan: 2006. Alternative Smoking Regimes. The CORESTA Task Force Report; Available at http://www.coresta.org/Reports/Alternative-SmokingRegimes-TF_FinalReport_July2006.pdf(Accessed June 2013)

Corresponding author:

Stephen W. Purkis

Imperial Tobacco Limited

Winterstoke Road,

Bristol BS3 2LL, UK

E-Mail: steve.purkis@uk.imptob.com 